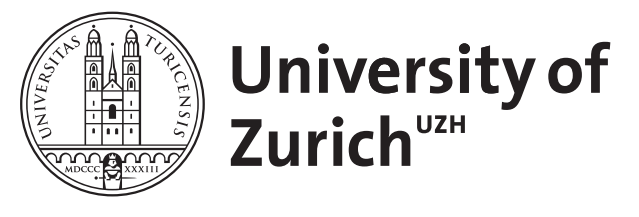

\title{
Overvalued: Swedish monetary policy in the 1930s
}

\author{
Rathke, Alexander ; Straumann, Tobias ; Woitek, Ulrich
}

\begin{abstract}
The article discusses Sweden's monetary policy in the 1930s, which has been hailed as the first and only example of successful price-level targeting. Our contribution is twofold. First, we argue that the crucial measure that immediately ended deflationary expectations and enabled a swift recovery was a strong and involuntary devaluation of the currency, not the adoption of a new monetary policy framework. Second, starting from the recent literature on monetary policy at the zero-lower bound, we conclude that Sweden's exchange rate policy is more relevant for the current discussion than its tentative experience with price-level targeting.
\end{abstract}

DOI: https://doi.org/10.1111/iere.12254

Posted at the Zurich Open Repository and Archive, University of Zurich ZORA URL: https://doi.org/10.5167/uzh-142851

Journal Article

Accepted Version

Originally published at:

Rathke, Alexander; Straumann, Tobias; Woitek, Ulrich (2017). Overvalued: Swedish monetary policy in the 1930s. International Economic Review, 58(4):1355-1369.

DOI: https://doi.org/10.1111/iere.12254 


\title{
Overvalued: Swedish Monetary Policy in the
}

\section{0s}

\author{
Alexander Rathke, Tobias Straumann, ${ }^{\dagger}$ and Ulrich Woitek ${ }^{\ddagger}$ \\ University of Zurich
}

November 16, 2015

\begin{abstract}
Since the financial crisis of 2008-09 economists have rediscovered price level targeting as an alternative to inflation targeting. The paper discusses Sweden's monetary policy in the 1930s which has been hailed as the first and only example of successful price level targeting. Our contribution is twofold. First, we argue that the crucial measure that immediately ended deflationary expectations and enabled a swift recovery was a strong and involuntary devaluation of the currency, not the adoption of a new monetary policy framework. Second, starting from the recent literature on monetary policy at the zero-lower bound, we conclude that Sweden's exchange rate policy is more relevant for the current discussion than its tentative experience with price level targeting.
\end{abstract}

${ }^{*}$ Corresponding author: ETH Zurich, KOF Konjunkturforschungsstelle, Leonhardstrasse 21, CH-8092 Zurich, Switzerland; rathke@kof.ethz.ch; CESifo Munich.

${ }^{\dagger}$ Department of Economics, Chair of Economic History, Zuerichbergstrasse 14, CH-8032 Zurich, Switzerland; tobias.straumann@econ.uzh.ch.

${ }_{\ddagger}^{\ddagger}$ Department of Economics, Chair of Economic History, Zuerichbergstrasse 14, CH-8032 Zurich, Switzerland; ulrich.woitek@econ.uzh.ch; CESifo Munich. 


\section{Introduction}

The recent financial crisis has led to a discussion about the effectiveness of monetary policy at the zero lower bound. One of the proposals that have received much attention is price level targeting as an alternative to inflation targeting. Notably, Charles L. Evans, President of the Federal Reserve Bank of Chicago, joined the ranks of those advocating a "state-contingent price-level target". According to him, it would help the public's understanding of the Fed s intentions in the current situation, if the central bank clearly communicated "an expected path for prices" (Evans, 2012, p. 147). Blanchard et al. (2013, p. 10) "would allow for higher inflation rates without undermining central bank credibility in the long run". And more recently, Narayana Kocherlakota, President of the Federal Reserve Bank of Minneapolis, showed some sympathy for price level targeting (Kocherlakota, 2014). ${ }^{1}$

The current discussion about price level targeting is linked to the academic research on the long stagnation of the Japanese economy since the early 1990s. Several macroeconomists have developed new ideas in order to improve the effectiveness of monetary policy at the zero lower bound (e.g. Krugman, 1998; Eggertsson and Woodford, 2003). Svensson (2003) provides a useful summary of all these suggestions and formulates a "foolproof way to escape from a liquidity trap". Svensson lists three conditions for a successful strategy: an upward-sloping price-level target path, a depreciation and a crawling peg of the currency, and an exit strategy. The gist of his argument is that communicating an upward-sloping price-level target path is not sufficient - in addition, depreciation is needed as a credible commitment to an increase in the future price level, which in turn leads to a reduction in the real interest rate by changing expectations.

\footnotetext{
${ }^{1}$ See Ambler (2009), Böhm et al. (2012), and Hatcher and Minford (2014) for a survey of the literature on pioneering work on price level targeting. For a thorough discussion of new approaches to monetary policy see e.g. English et al. (2013).
} 
This paper tries to make a historical contribution to the ongoing debate about alternative monetary policy regimes. It discusses Sweden's monetary policy in the 1930s that is said to have been the first time a central bank has truly adopted price level targeting. In particular, it asks how the policy of the Riksbank contributed to the strong recovery of the Swedish economy after the suspension of the gold standard in September 1931. Against the background of the current discussion, it seems natural to conjecture a close relationship between price level targeting and the performance of the real economy. Ending deflationary expectations was one of the most important conditions for recovery in the 1930s (Eichengreen, 1992). We agree with the observation that the Riksbank in fact made a crucial contribution to the rapid recovery of the Swedish economy, but we are skeptical of the view that price level targeting played a crucial role. Our argument has three parts. First, a close reading of the archival sources suggests that it is far from certain that the Riksbank truly adopted price level targeting in the first place (Section 2). In this, we follow Berg and Jonung (1999), but we differ in that we add new evidence leading us to be even more critical towards the motives of Riksbank governor Rooth than Berg and Jonung. Secondly, we argue that even if the Riksbank had adopted price level targeting, it is doubtful whether the mere stabilization of prices that occurred in Sweden after 1931 was sufficient to end deflationary expectations. As noted, in today's discussion price level targeting refers to a rising path of prices, not to a stabilization of prices as in Sweden's official monetary program of 1932. Likewise, in their analysis of the British recovery in the 1930s, Crafts and Fearon (2013, pp. 56-57) argue that the credible commitment to maintaining inflation, not price stability, proved crucial for ending deflationary expectations. Thirdly, our analysis shows that the devaluation ended deflationary expectations almost immediately and that the quick recovery of the Swedish economy was mainly driven by the undervaluation of the Swedish krona after September 1931. It is as Charles Kindleberger suspected almost 40 years ago in his standard reference on the world economic crisis: "the recovery 
represented simple exchange depreciation in excess of that of the pound, plus spillover from the British building and later armament boom" (Kindleberger, 1973, p. 182).

To measure the effects of the devaluation and to track the change of inflationary expectations, we estimate a dynamic stochastic general equilibrium (DSGE) model for a small open economy (Section 4). Despite its relatively simple structure, this model adequately captures the key dynamics of the factors driving the Swedish economy in the period under analysis. We show that, by keeping the krona undervalued, Swedish exchange rate policy enabled Sweden to avoid a much deeper and prolonged depression. The fact that Sweden escaped from depression and deflation with the aid of a strong devaluation, but without announcing an upward-sloping price-level target path, may be relevant for the foolproof way as suggested by Svensson (2003). For the central bank of a small open economy like Sweden, it may be sufficient to use exchange rate policy to convince markets of its resolve to make a fundamental change in its monetary policy.

\section{Sweden's Price Level Targeting}

On Sunday evening, September 27, 1931, the Swedish finance minister Felix Hamrin announced the temporary suspension of the gold standard and declared that from now on "monetary policy should be aimed at stabilizing the internal purchasing power of the krona by all means possible".2 Ten days later, the Board of the Riksbank decided to ask three renowned Swedish economists, Gustav Cassel, David Davidson, and Eli Heckscher, to explain "what guidelines should be carried

\footnotetext{
${ }^{2}$ Bankoutskottets utlåtande Nr 40, Bihang till riksdagens protokoll 1932 (May), p. 8: "att penningpolitiken syntes böra inriktas på att med till buds stående medel bevara den svenska kronans inhemska köpkraft". A complete timeline of relevant events is included in the appendix.
} 
out for the development of the Swedish monetary system". ${ }^{3}$ Another two weeks later, the responses of the three economists arrived at the Riksbank. They contained very innovative and useful instructions on how to conduct monetary policy under a floating exchange rate. The Riksbank constructed a weekly consumer price index in order to have a better picture of the effects of its monetary policy. Officially, the krona was now on a paper standard, and the Riksbank pursued price level targeting.

Ever since Hamrin's declaration in September, 1931, economists have debated the question whether or not the Riksbank truly abandoned exchange rate targeting and aimed at stabilizing the domestic price level. Irving Fisher was among the contemporaries who believed that the Riksbank indeed adopted a new framework. In his book Stabilized Money (1935) he highlighted the extraordinary stability of the Swedish price level after September 1931 and pointed out that the Riksbank "had to make use of much active management" in order make this happen (p. 324). He was also impressed by the communication strategy of the monetary authorities. "Thus", he concluded, "for the first time in history, a country announced its policy would be that of stabilizing its currency, not with regard to gold or with regard to foreign exchange, but with regard to the internal purchasing power of its money" (p. 320).

There is no doubt that the Swedish price level was stable after September 1931. For five years, the consumer price index of the Riksbank remained within a band of \pm 5 percent (Figure 1). As for the role of the central bank, however, Fisher's enthusiastic view was challenged by many contemporary economists, among them Erik Lindahl who provided a "good-luck interpretation" for Sweden's price stability (Lindahl, 1936, p. 95). Brinley Thomas (1936, p. 233) called Fisher's explanation of the Swedish success a "naïve gospel", and Richard A. Lester (1939, p. 279) concluded that the Riksbank behaved as if Sweden were still on a gold

\footnotetext{
${ }^{3}$ Särskilt protokoll, 8 October: "[...] sina synpunkter angående vilka riktlinjer enligt deras mening borde uppdragas för det svenska penningväsendets utveckling".
} 
standard.

After World War II, economists lost interest in the monetary experiments of the interwar years as the Bretton Woods system seemed to rehabilitate a system of fixed exchange rates. But in the 1970s when floating exchange rates became a viable option, researchers began to rediscover Sweden's monetary policy of the 1930s. The pioneer of this rediscovery has been the Swedish economist Lars Jonung. After publishing two seminal papers in the late 1970s (Jonung, 1979b,a), he resumed the topic in the late 1990s when inflation targeting had become the new standard for central banks (Berg and Jonung, 1999; Fregert and Jonung, 2004).

Jonung takes a nuanced view. While stating that the monetary program served as a guiding principle for the Riksbank's policy, he detects several deviations from the official declarations. In November 1931 and again in late 1932 the Board of the Riksbank tried to restore the old parity with sterling at 18.16 kronor, thus inducing a period of deflation. Ultimately the attempt to appreciate the krona failed, but not because its members saw that such a strategy was not compatible with the goal of price level targeting, but because they lacked the reserves to maintain the old parity. Jonung also points out that the Riksbank, after pegging the krona to sterling in the summer of 1933, failed to let the currency appreciate in late 1936 when the Sweden imported inflation from Great Britain. Figure 1 summarizes the violations of the rules of price level targeting. 
Figure 1: Nominal Exchange Rate SKr./£ and Swedish CPI

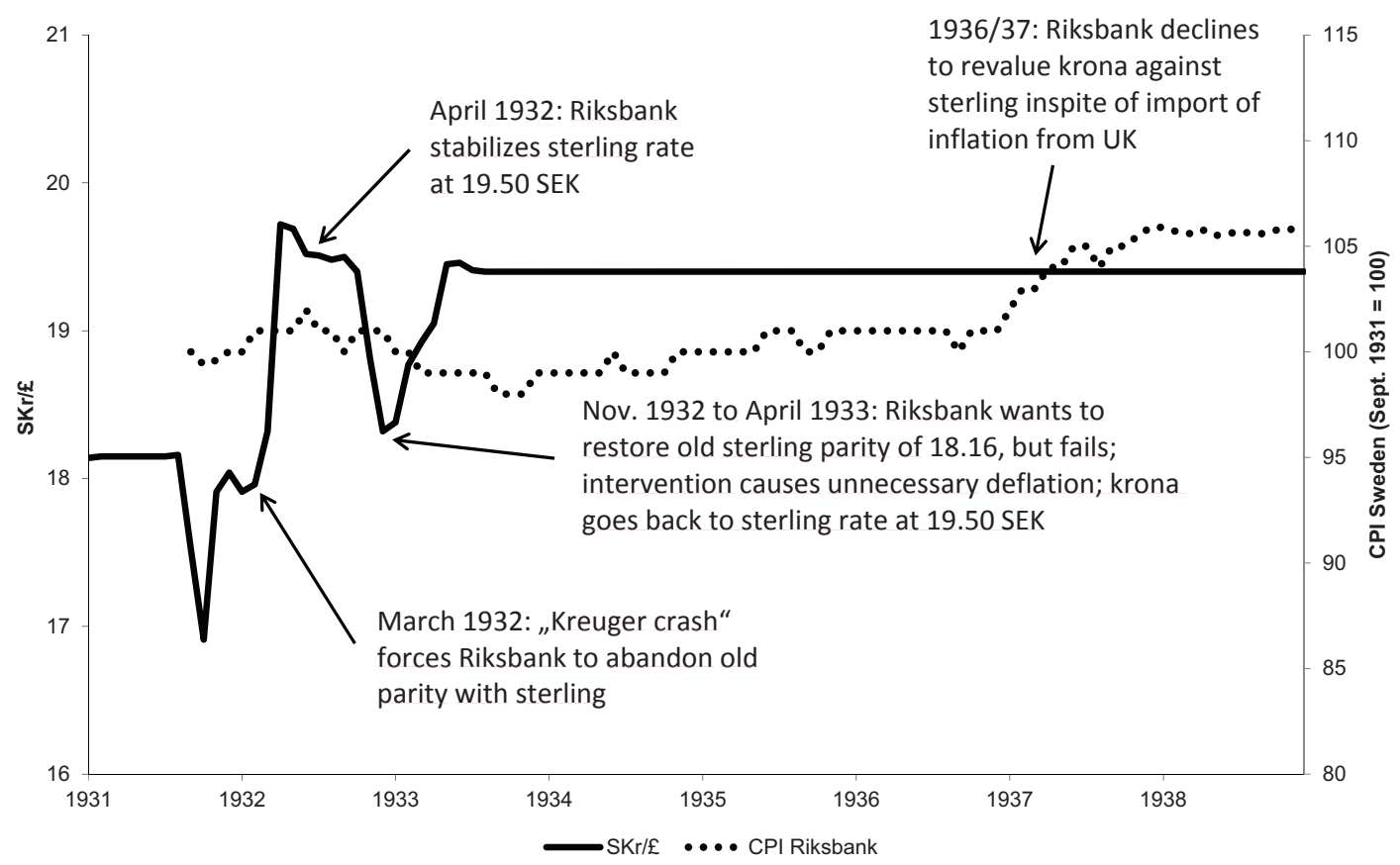

Source: Riksbank

In recent times, Jonung's pioneering work was followed up and carried further by Straumann and Woitek (2009). Like Thomas (1936) and Lester (1939), they argued that the frequent violations of the rules of price level targeting are hard to reconcile with the claim that the Riksbank was primarily guided by the new monetary program. Furthermore, they were the first to analyze the original documents of the central bank and to provide an econometric test. Their analysis suggests that the Riksbank and in particular governor Ivar Rooth pursued a traditional approach by aiming at a stable exchange rate against the pound as the main goal, not as an intermediate target in order to stabilize the price level, but as the end in itself. Two other recent papers support this skeptical view (Cournéde and Moccero, 2009; Böhm et al., 2012).

The private letters of Ivar Rooth are particularly illuminating. In late September 1933, he explained to O.M.W. Sprague, professor of economics at Harvard and 
temporary assistant to the United States Secretary of the Treasury:

"My personal opinion is that it is of the utmost importance to the whole economic life of a nation which like Sweden for its standard of living is to such a great extent depending upon foreign trade, to have fairly stable quotations. I think that I dare say that also in order to get a rising price-level, stable foreign exchanges are better than the erratic movements of these rates which the world has suffered from ever since September 1931."

Rooth also made it clear to Sprague that a depreciation of the krona resulted from the need to accumulate foreign exchange reserves after November 1931:

"When we were driven off the Gold Standard in September 1931 we had less gold than usual and hardly any foreign exchange reserves. As there was then a stipulation in our law that we were allowed to issue notes to not more than double the amount of our gold reserve plus 250 million kronor, we could not reduce our gold holdings. In order to get some hold of the development of the Swedish exchange and the price level we had to try to build up a foreign exchange reserve. [...] A consequence of this policy of ours was that on the whole the foreign exchange quotations rose." 5

In addition, in early 1936 Rooth argued in a letter sent to the Swiss National Bank that Sweden pegged the krona rate to sterling because most foreign business was invoiced in sterling:

"It was particularly important for a small country like Sweden depending so strongly on its foreign trade to inspire trade and industry with trust in our currency." 6

\footnotetext{
${ }^{4}$ Archives Bank of England, OV 29/26 (26 September 1933).

${ }^{5}$ Archives Bank of England, OV 29/26 (26 September 1933).

${ }^{6}$ Archives Riksbank, Rooth papers, box 93 (correspondence with Swiss National Bank).
} 
And finally, in a further statement in February 1938, Rooth wrote to Randolph Burgess, Vice-President of the Federal Reserve Bank of New York:

"Some American professors, e.g. Professor Irving Fisher, believe that it is an achievement by us in the Riksbank that prices have been fairly steady up to the middle of 1936. I have told Professor Fisher before and I am sorry to have to tell you now that what we have done is merely that we have carried out a fairly conservative central banking policy. In fact we have never tried to do anything directly with regard to prices." 7

In accordance with the new literature on the divergence between words and deeds in central banking (Reinhart and Rogoff, 2004; Levy-Yeyati and Sturzenegger, 2005), these personal letters and other written sources suggest that there was a gap between the discourse among economists and politicians and the rationale behind the actions taken by governor Rooth and the Board of the Riksbank. And interestingly, the price level of Norway was even more stable after September 1931 than the Swedish one, although the monetary authorities in Oslo did not announce a new policy regime after the suspension of the gold standard in late September 1931 (Venneslan, 2010). The innovative character of Sweden's monetary policy appears to be overvalued.

Most importantly, even if we accept that price level targeting was adopted by the Riksbank, it is not clear how it was supposed to contribute to the recovery of the Swedish economy. As Crafts and Fearon (2013) emphasize in their discussion of the British recovery after the suspension of the gold standard in September 1931, the announcement of a rising price level was crucial to generating inflationary expectations. In July 1932, Neville Chamberlain, the British Chancellor of the Exchequer that ran monetary policy after 1931 announced a price-level target which aimed to end price deflation and return prices to the 1929 level, and he

\footnotetext{
${ }^{7}$ Archives Sveriges Riksbank, Rooth papers, Box 129 (10 February 1938).
} 
repeated it many times in the next few years. We don't see a comparable communication by Sweden's monetary authorities. On the contrary, the May 1932 monetary program as framed by the Banking Committee of the parliament stated that the Riksbank was supposed to avoid deflation as well as inflation and that "a targeted recovery of prices was not supposed to go back to a price level that was too distant." ${ }^{8}$ Accordingly, Böhm et al. (2012, p. 14) are right in pointing out in their discussion of the Swedish case that "[i]t can also be argued that the transition from the gold standard to price-level targeting (and back) did not represent a significant change in monetary policy, as the gold standard was de facto price-level targeting determined by the price of a single commodity - gold".

For all these reasons, we pursue a different path when analyzing how the Riksbank's monetary policy contributed to the early and strong recovery of the Swedish economy. In the next two sections, we will try to show that the strong undervaluation of the krona was the crucial operation which jump-started the economy and ended deflationary expectations. And archival sources show that the strong undervaluation did not result from a deliberate policy choice, but from the need to replenish foreign exchange reserves that determined the Riksbank's exchange rate policy. Thus, in the letter to Sprague which we have already cited above governor Rooth explained that the strong recovery of the economy was an unintentional effect of the Riksbank's urgent need for foreign exchange reserves. After Britain and Sweden suspended the gold standard in September 1931, the krona was undervalued against sterling, and sterling was undervalued against the US dollar and the French franc. At the same time the Riksbank followed the Bank of England in lowering interest rates in the first half of 1932, though only reluctantly, because it feared a sudden surge of inflation. No wonder, the British monetary authorities were not impressed by Sweden's public discussions about price level targeting. In late 1936, Montagu Norman, governor of the Bank of

\footnotetext{
${ }^{8}$ Bankoutskottets utlåtande, No. 40, May, 1932, p. 18.
} 
England, made the following observation:

"The Swedes have made a lot of noise about their new monetary policy of basing the level of the krona on a price index and thus maintaining the level of prices. In fact they have up till now had to do nothing but keep pegged on sterling and we have kept their prices steady for them." 9

\section{Explaining the Swedish Recovery}

From a comparative perspective, Sweden's economic crisis in the 1930s was short. Not only did it start later than in most European countries, it also ended sooner than elsewhere. In 1930, when countries like Germany and the United States were sliding into a severe recession, Sweden still enjoyed positive, albeit moderate growth. And in 1933, when the members of the gold bloc under the leadership of France still had three years of depression before them, Sweden already experienced the beginning of a rapid recovery. By 1937, when the US barely reached the level of 1929 in terms of real GDP, the Swedish economy had grown by 25 percent relative to the peak before the crisis. The spurt of the industrial sector was particularly impressive. In 1937, Sweden's index of industrial production was at 152 relative to the level of 1929 while the indices of countries that also enjoyed a swift recovery, namely Denmark, Norway, and the UK, were 135, 130, and 130, respectively.

The analysis of the main components of real GDP reveals that the recovery changed its character over time (Figure 2). In 1932, the improvement of the trade balance was the only component checking the economic contraction, as exports declined less than imports (-225.4 mio. and -308.3 mio. SKr. respectively). The recovery had not started yet, but at least the slide into the depression was

\footnotetext{
${ }^{9}$ Archives Bank of England, OV 29/27 (31 December 1936).
} 
slowed. In 1933, however, the forces of recovery began to be visible in overall GDP growth $(+2.2 \%)$, as the trade balance further improved ${ }^{10}$ and firms began to invest in new machinery. Yet, since the investment in the real estate sector continued to decline and consumers were still tightening the belt, GDP in 1932 remained below the level of 1930 .

In 1934 recovery was fully under way, as consumption and investment markedly increased. The strongest stimulus came from the rise of private consumption, whereas government consumption turned from negative to barely positive. The Social Democratic government, elected in the autumn of 1932, aimed to pursue a countercyclical fiscal policy, but obviously failed to mobilize the sums necessary to provide an additional boost to the economy. In 1935, the Swedish economy was already near full employment, as private consumption and investment further increased. Unemployment fell from 9.6 percent in 1933 to 6.2 percent in 1935 (Grytten, 1995). Clearly, Sweden had overcome the depression within three years.

Figure 2: Sweden's Real GDP, 1932-35

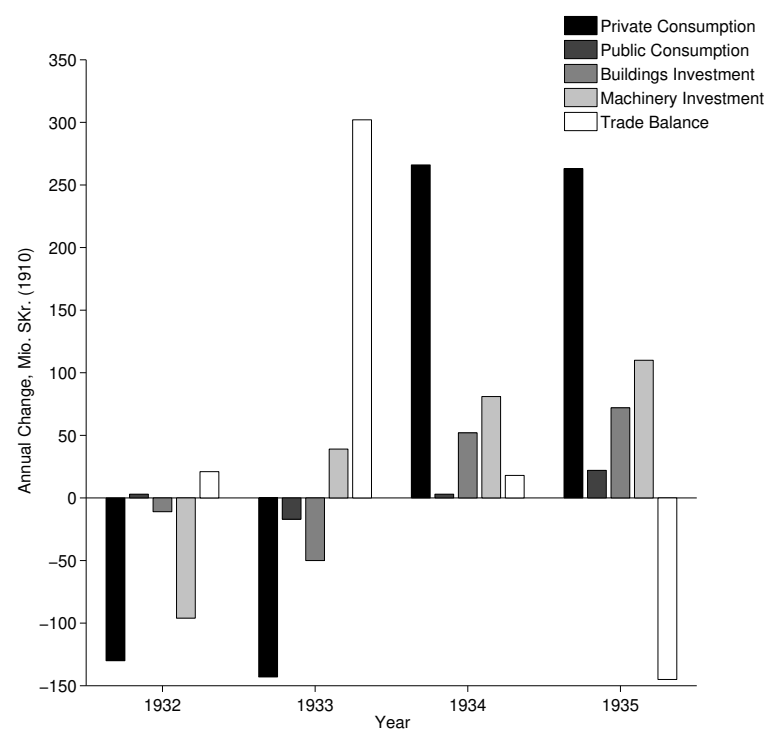

Source: Schön and Krantz (2012)

\footnotetext{
${ }^{10}$ More details on the composition of foreign trade during the recovery can be found in the appendix.
} 
Sweden's recovery was influenced by the rising demand of the world economy after 1932. The suspension of the gold standard and the devaluation of the currency in the UK in September 1931 and in the US in April 1933 marked the beginning of the end of the crisis at the global level (Eichengreen and Sachs, 1985). Yet, Sweden's recovery also seemed to be driven by the undervaluation of the exchange rate. One of the first to bring up the issue of undervaluation was Montgomery (1938), and in recent times, the issue was reintroduced to a broader audience by Kindleberger's question cited in the introduction. The first to study the topic in a more systematic way was Lundberg (1983). On the basis of purchasing power parities, he estimated that from 1932 to 1935 the krona was undervalued by 15 percent. He also discussed the question why the undervaluation did not cause inflation at an earlier stage of the expansion. His answer was twofold. First, demand elasticity was rather high, i.e. foreign customers of Swedish products reacted strongly to the lowering of prices after the end of the gold standard in 1931. Second, the access to natural resources (wood, iron ore) was relatively cheap as domestic producers provided them.

Figure 3: Change in Real Exchange Rate

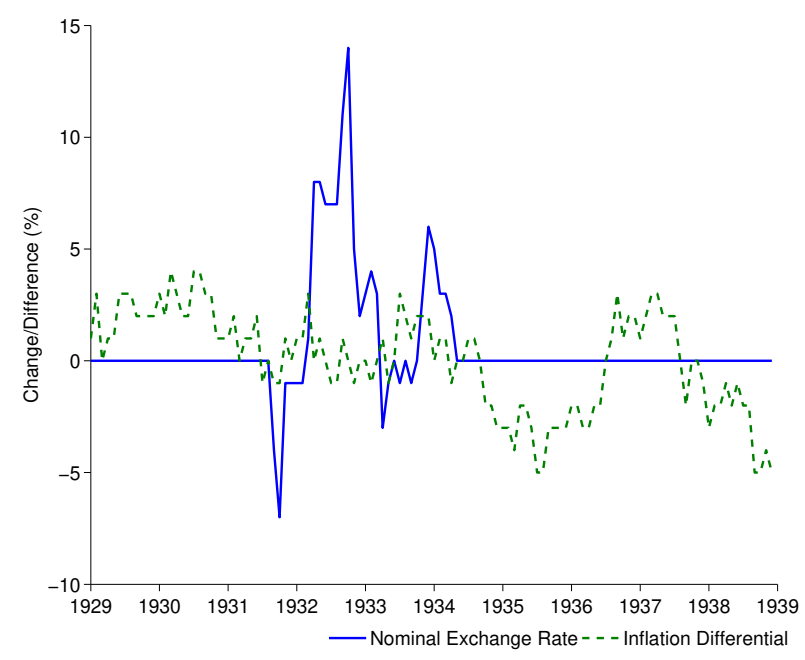

Source: Sveriges Riksbank, Årsbok, various years. 
Our back-of-the-envelope calculation confirms Lundberg's finding. We computed the real exchange rate of the krona against sterling based on foreign and domestic prices and the nominal exchange rate, and as an initial approximation, we consider only the percentage changes in the real exchange rate. The results in Figure 3 of this simple exercise are quite clear. Already in 1930, when the nominal exchange rate was fixed, the Swedish inflation rate was lower than in Britain, implying a real depreciation of the Swedish currency. The nominal devaluation in September 1931 then reinforced the real depreciation. The question remains as to the effects of this depreciation, which we will analyse in detail in the next section.

Figure 4: Gold and Foreign Exchange Reserves of the Riksbank

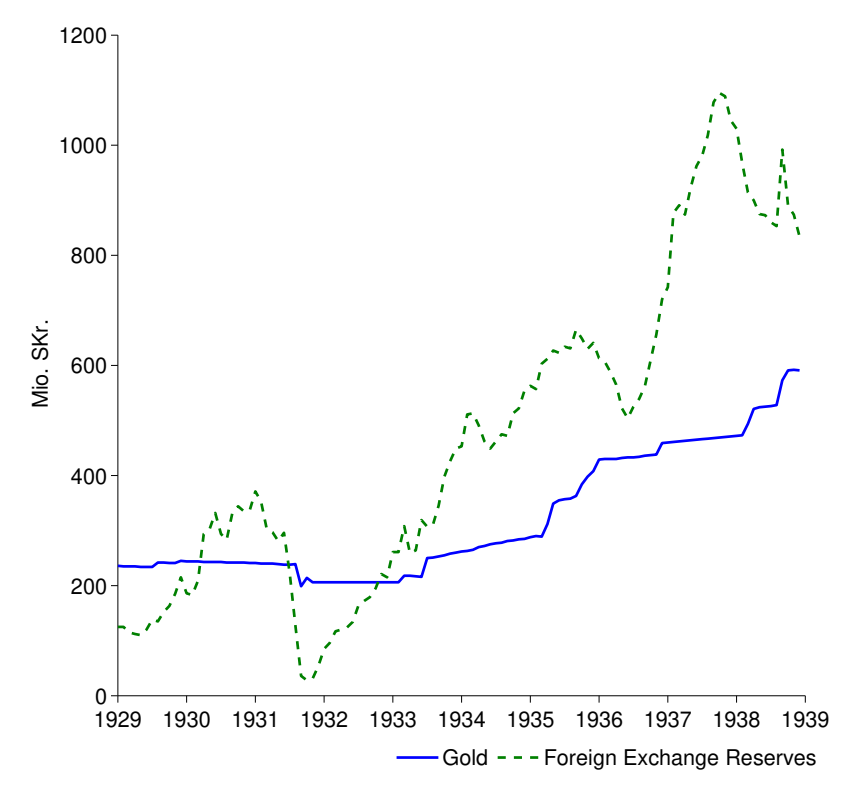

Source: Sveriges Riksbank, Årsbok, various years.

A further piece of evidence suggesting a marked undervaluation is the strong rise of gold and foreign exchange reserves of the central bank. In the first six months of 1929 (that is, before the beginning of the world economic crisis), Swedish gold and foreign exchange reserves amounted to 350 million SKr; by the end of 1935 they reached 1,000 million SKr (Figure 4). This increase of reserves was so steep 
that the Bank of England observed in a memo in January 1936 that ". . . the Riksbank is still holding an abnormally large share of Sweden's abnormally large foreign reserves".

The dramatic improvement in the trade balance after 1931 is another sign that the Swedish currency was most probably undervalued. In 1931/32, the trade balance was extremely negative, since Sweden, as a small open economy, was suffering immensely from the collapse of world trade (Figure 5). By 1933/34, the trade deficit had disappeared, partly because of the recovery in exports. In 1932, the worst year of the depression, they amounted to 947 million SKr and two years later in 1934 to 1,302 million SKr. During the same period, imports increased by just 150 million SKr, from 1,155 to 1,305 million SKr despite of protectionist measures by Sweden's trading partners.

Given that from 1932/33 the UK pursued a protectionist trade policy and that Germany forced clearing agreements on its trading partners, the strong rise of exports may come as a surprise. Yet, new research has shown that the Scandinavian countries were able to defend their export interests quite successfully (Olsson, 2010). It is true that the British turn towards protectionism as established at the Ottawa conference in 1932 was a major blow to Sweden s economy, especially for the timber, pulp and paper as well as the steel industries. Yet, thanks to tenacious negotiations, Sweden was able to mitigate the negative effects of British protectionism. In exchange for a higher quota of coal imports from the UK, the Swedish pulp and newsprint sector was freed of British duties and the paper and steel industries received a marked reduction of British tariffs. Consequently, Sweden's traditional trade surplus with the UK became smaller, but did not disappear after 1932. Likewise, the agreement with Germany was relatively favorable. The traditional view that the Nazi government exploited its smaller trading partners seems to be incorrect. The clearing agreements that were renewed annually made it possible that Sweden profited from the rising demand of the German economy (Hedberg, 2010). Sweden's traditionally high 
trade deficit with Germany shrank after $1931 .^{11}$

Figure 5: Current Account Visibles and Invisibles, Sweden

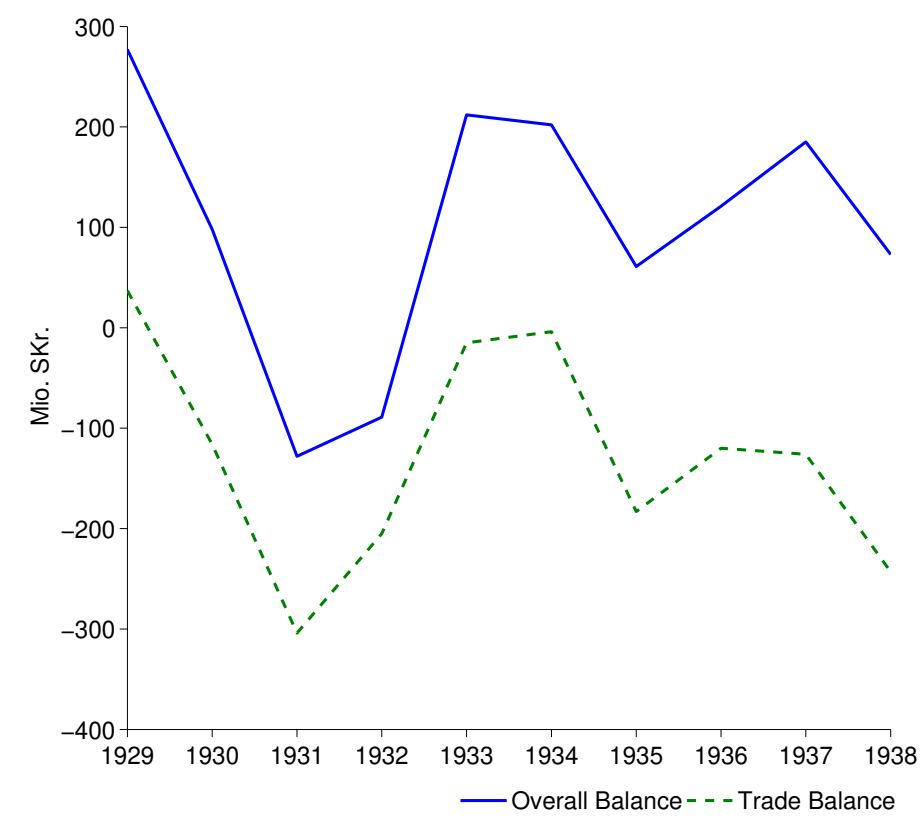

Source: Mitchell (2003, Table J3).

\section{Model and Results}

To shed more light on the reasons behind Sweden's rapid recovery, we use a simple dynamic stochastic general equilibrium (DSGE) model in the spirt of Galí and Monacelli (2005); Monacelli (2005). ${ }^{12}$ The model is a small open economy model in the New Keynesian tradition of Clarida et al. (1999, 2000); Woodford (2003) and incorporates nominal rigidities and imperfect competition. We estimate the model using Bayesian methods and use the model to illustrate that the

\footnotetext{
${ }^{11}$ For a broader view of Scandinavia's position between Germany and the UK see Salmon (2010).

${ }^{12}$ Similar models have been used successfully been used among others by Smets and Wouters (2002); Bergin (2003, 2006); Lubik and Schorfheide (2006, 2007); Ambler et al. (2004); Justiniano and Preston (2010a,b); Adolfson et al. (2008, 2007); Burriel et al. (2010); Dib (2011).
} 
depreciation of the Krona was the key trigger for the recovery.

The model includes households consuming and investing in physical capital, which is rented out to firms owned by the households. Households have access to a full set of internationally traded state contingent claims denoted in domestic currency. ${ }^{13}$ The domestic intermediate goods sector is characterised by monopolistic competition. Firms rent capital and labor services from the households. A bundler sells a the final domestic good to the households and an importing firm imports and sells a composite foreign good. There are shocks to the domestic currency price of foreign goods, to world demand for domestic goods, and to the risk sharing condition that allows for deviations from perfect risk sharing. As the model is fairly standard a more detailed description can be found in an appendix. To identify the empirical implications of the model, we use monthly data on industrial production, inflation, the export/import ratio, and the real exchange rate for the observation period January 1928-September 1939. Based on the consumer price index published by the League of Nations, we calculated inflation as the seasonal first differences of the price index in logs and then demean. The real exchange rate data is from the Riksbank, and the export/import ratio (seasonally adjusted) is from Statistika Centralbyrån (1972). Industrial production (seasonally adjusted) is from the League of Nations; following Rabanal and Rubio-Ramírez (2005), we calculated the log-deviation from a quadratic trend. We also smooth the real exchange rate using a 7 month moving average to remove short-term noise in the real exchange rate.

To avoid stochastic singularity, we use measurement errors for output, inflation and the export/import ratio. To generate the parameter chain, we use the tailored randomized Markov chain Monte Carlo (MCMC) method proposed by Chib and Ramamurthy (2010). The simple model reproduces the stylized facts of the Swedish economy in the 1930s reasonably well. Figure 6 compares data with me-

\footnotetext{
${ }^{13}$ We abstract from financial market incompleteness, as this plays no role in our proposed explanation.
} 
dian predictions of the model. The dynamics implied by the estimated structural shocks for the four observed variables fit in a satisfactory way. By construction, the real exchange rate is matched perfectly, ${ }^{14}$ and therefore not reported here. We have also added a measure for annual world output not used in the estimation procedure for comparison. Plotting the estimated world demand shock against an annual world manufacturing index taken from the historical data on international merchandise trade statistics published by the United Nations, we find that our estimated shock mimics the actual movements almost perfectly.

Figure 6: Model Fit
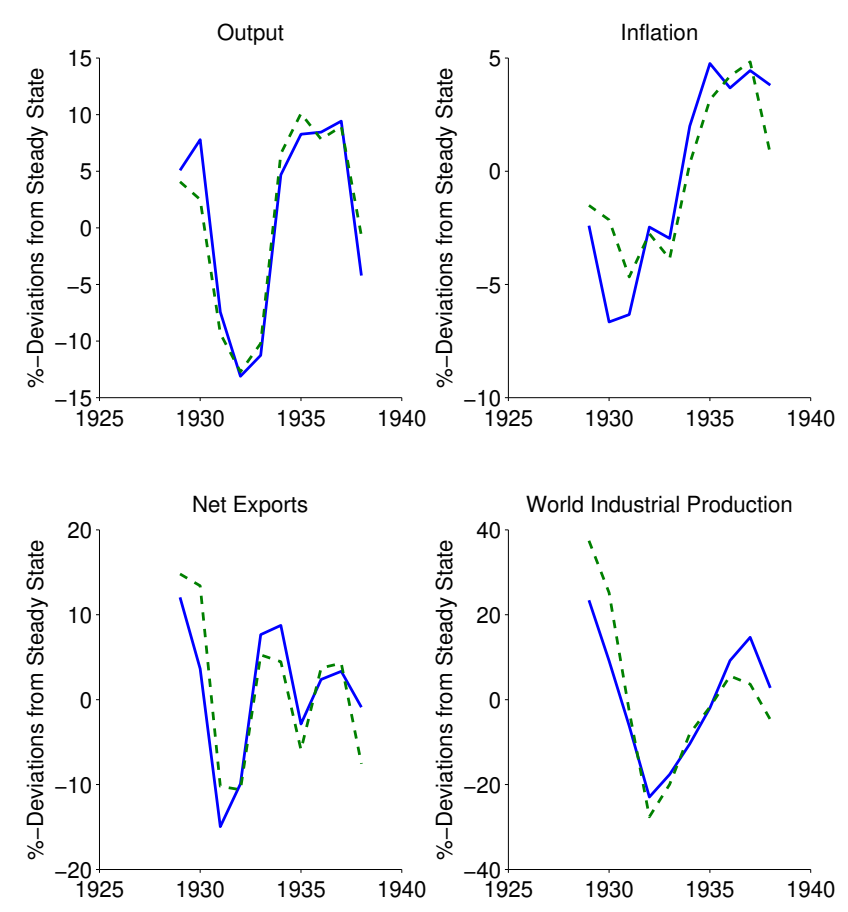

To evaluate the effect of the Krona devaluation we use a counterfactual in which the Krona is not devalued. To this end, we adjust the exogenous process that models the domestic price of foreign goods, which includes the change in the

\footnotetext{
${ }^{14}$ Because of the absence of a measurement error in the measurement equation for the real exchange rate. This facilitates our counterfactual analysis later.
} 
nominal exchange rate. We set it to be consistent with the real exchange rate that would have been the result if the nominal Krona-Sterling rate would have been stuck at the September 1931 value. The consequence would have been that instead of being undervalued after 1932, the Swedish currency would have been constantly overvalued as displayed in the lower left panel of Figure 7 .

Figure 7: Counterfactual Experiment
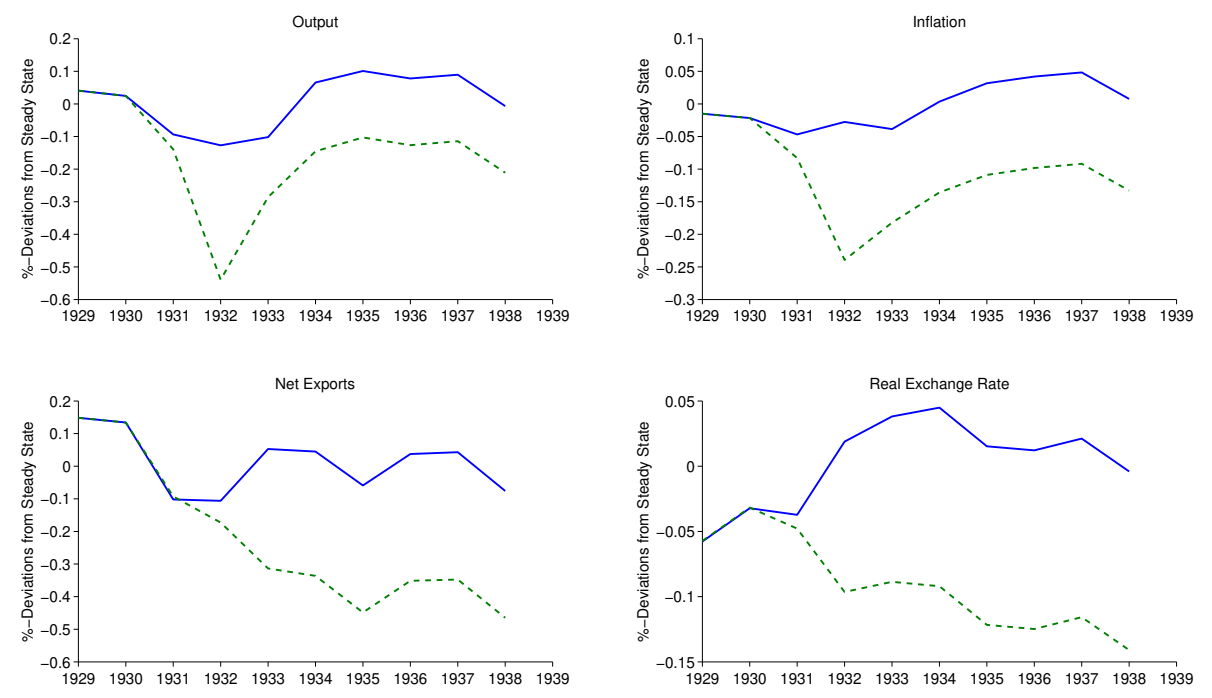

The new real exchange rate is accompanied by a considerable drop in economic activity from 1932 onwards. In 1932 we see a massive recession which is much more severe then the actual observed, for Depression standards rather modest, decline in industrial production. The strong recovery in net exports evaporates, but still, the economy recovers with the recuperating world economy after 1933 . Without the depreciation we observe no exit from deflation. Looking deeper into inflation dynamics, Figure 8 zooms into the depreciation episode.

Between 1931 and 1934 the model implied one year-ahead inflation expectations follow closely the movement of the nominal exchange rate and briefly venture back into positive territory in 1932 when the nominal exchange rate was at its weakest level, but actual inflation was still negative. When the Swedish authorities 
unnecessarily tried to bring the Krona back to the old parity inflation expectation are again pushed sightly below zero. However, this is in sharp contrast to our counterfactual scenario. In the counterfactual scenario inflation expectations remain firmly in negative territory, as shown in the center panel of Figure 8.

Figure 8: Inflation Expectations
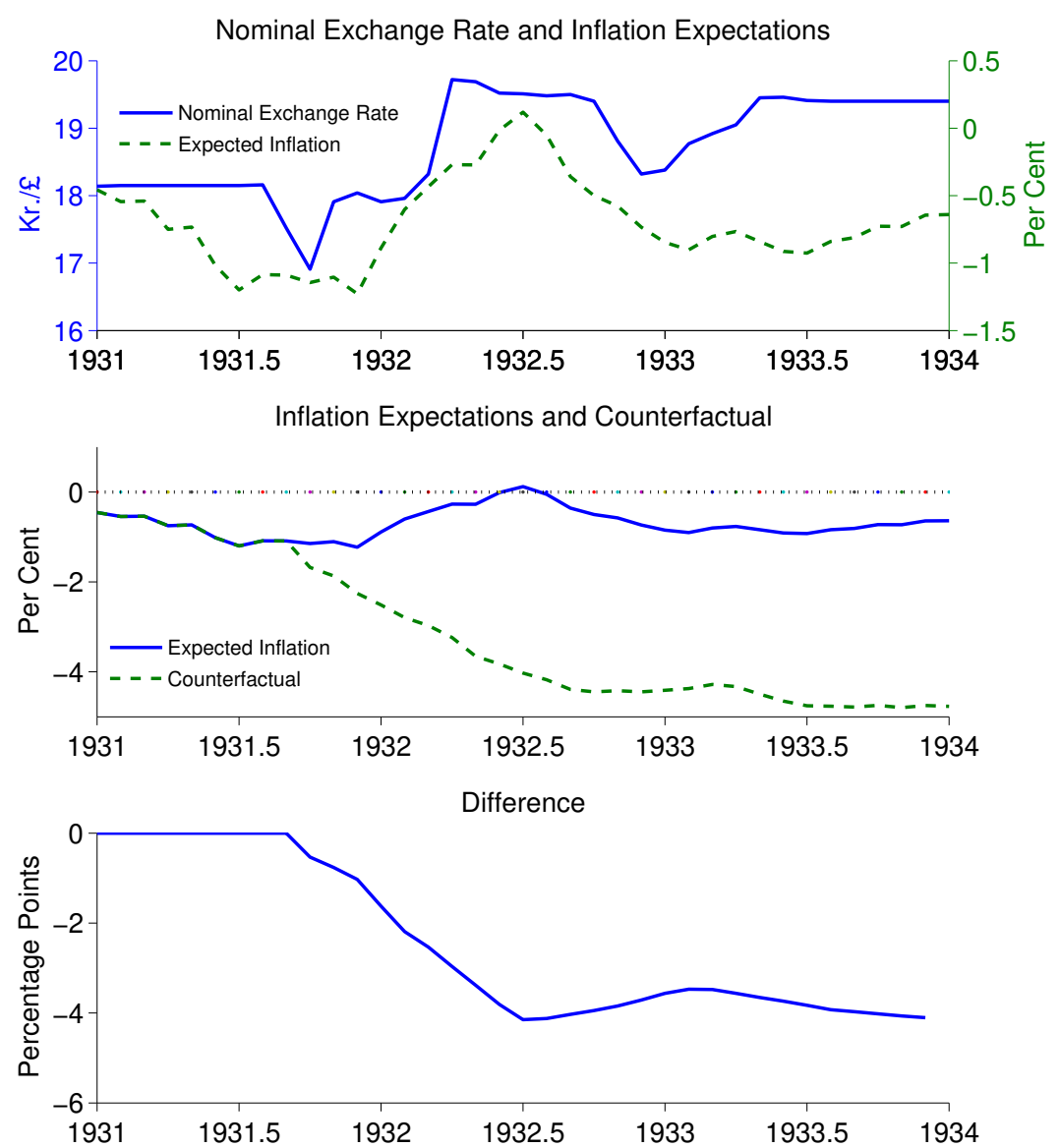

There are some points to mention. On the one hand, our scenario represents a lower bound for the effect as there would have been a further appreciation of the real effective exchange rate when the USA abandoned the Gold Standard in 1933 which we have not considered here. On the other hand, inflation would have been lower without depreciation and hence the target real exchange rate would have 
depreciated somewhat.

\section{Conclusion}

Sweden was among the first economies to recover from the depression in the early 1930s, and it did so in a particularly impressive way. We test the contribution made to this recovery by Sweden's monetary policy. Building on Lundberg (1983), who claimed on the basis of descriptive statistics that Sweden consciously kept its currency undervalued vis-à-vis the British pound, we apply a DSGE model for a small open economy. Our results show that Sweden's exchange rate policy in fact had a strong impact on the course of recovery. Our counterfactual simulations indicate that that the depreciation of the krona prevented a much deeper and prolonged downturn in economic activity. The devaluation also changed inflationary expectations almost immediately.

This finding contributes to the ongoing discussion about alternative monetary policy frameworks. The Riksbank in the 1930s has been seen as an example of a relatively innovative central bank in terms of the conduct of monetary policy. We argue instead that this view overvalues the official declarations of Swedish officials. Before and after the suspension of the gold standard in 1931, the Riksbank was determined to have a stable currency, believing that it was a necessary condition for international trade and not just an intermediate target for monetary policy. Furthermore, the Riksbank's main motivation behind the strong undervaluation of the krona was the need to replenish its foreign exchange reserves, not the stabilization of the domestic price level. Crafts and Fearon (2013) have made the point that the policy framework adopted by the British Treasury from mid-1932 fulfilled the so-called "foolproof way" of escaping from the liquidity trap (Svensson, 2003). By pursuing a cheap-money policy, announcing a price-level target well above the current one and engineering a marked undervaluation of the pound, the UK was able to enjoy a strong economic recovery in the 1930s. 
Sweden was in a similar position as the UK, but fulfills only two of the three conditions listed by Crafts and Fearon (2013). In particular, the Swedish monetary authorities never announced a price level well above the current one, whereas the British Chancellor of the Exchequer Neville Chamberlain declared in mid-1932 that prices should rise to the level of 1929. This observation can be seen as a further piece of evidence supporting our argument that it was the involuntary, but clear break with the gold standard that signaled the end of deflation and helped Sweden overcome the depression more rapidly than other countries. 


\section{References}

Adolfson, M., S. Laséen, J. Lindé and M. Villani, "Bayesian Estimation of an Open Economy DSGE Model with Incomplete Pass-Through," Journal of International Economics 72 (July 2007), 481-511.

Adolfson, M., S. Laséen, J. Lindé And M. Villani, "Evaluating an Estimated New Keynesian Small Open Economy Model," Journal of Economic Dynamics and Control 32 (August 2008), 2690-2721.

Ambler, S., "Price-Level Targeting and Stabilisation Policy: A Survey," Journal of Economic Surveys 23 (2009), 974-997.

Ambler, S., A. Dib And N. Rebei, "Optimal Taylor Rules in an Estimated Model of a Small Open Economy," Working Papers 04-36, Bank of Canada, 2004 .

Berg, C. And L. Jonung, "Pioneering Price Level Targeting: The Swedish Experience 1931-1937," Journal of Monetary Economics 43 (June 1999), 525551.

Bergin, P. R., "Putting the 'New Open Economy Macroeconomics' to a Test," Journal of International Economics 60 (May 2003), 3-34.

_. "How Well Can the New Open Economy Macroeconomics Explain the Exchange Rate and Current Account?," Journal of International Money and Finance 25 (August 2006), 675-701.

Blanchard, O., G. Dell'Ariccia and P. Mauro, "Rethinking Macro Policy II: Getting Granular," Imf staff discussion note, IMF, April 2013.

BöHm, J., J. FiláčEK, I. Kubicová and R. Zamazalová, "Price-Level Targeting - A Real Alternative to Inflation Targeting?," Czech Journal of Economics and Finance 62 (2012), 2-26. 
Burriel, P., J. Fernández-Villaverde and J. F. Rubio-Ramírez, "MEDEA: a DSGE Model for The Spanish Economy," SERIEs 1 (March 2010), $175-243$.

Chib, S. and S. Ramamurthy, "Tailored Randomized-Block MCMC Methods for Analysis of DSGE Models," Journal of Econometrics 155 (2010), 19-38, forthcoming.

Clarida, R., J. Gali and M. Gertler, "The Science of Monetary Policy: A New Keynesian Perspective," Journal of Economic Literature XXXVII (1999), $1661-1707$.

Clarida, R., J. Galí and M. Gertler, "Monetary Policy Rules and Macroeconomic Stability: Evidence and some Theory," Quarterly Journal of Economics 115 (2000), 147-180.

Cournéde, B. And D. Moccero, "Is there a Case for Price-level Targeting?," OECD Economics Department Working Papers 721, OECD Publishing, August 2009.

Crafts, N. And P. Fearon, eds., The Great Depression of the 1930s. Lessons for Today (Oxford: Oxford University Press, 2013).

DiB, A., "Monetary Policy in Estimated Models of Small Open and Closed Economies," Open Economies Review 22 (November 2011), 769-796.

Eggertsson, G. B. And M. Woodford, "The Zero Bound on Interest Rates and Optimal Monetary Policy," Brookings Papers on Economic Activity 34 (2003), 139-235.

Eichengreen, B., Golden Fetters. The Gold Standard and the Great Depression 1919-1939 (Oxford: Oxford University Press, 1992). 
Eichengreen, B. And J. Sachs, "Exchange Rates and Economic Recovery in the 1930s," Journal of Economic History 45 (1985), 925-946.

English, J., William B., D. López-Salido and R. J. Tetlow, "The Federal Reserve's Framework for Monetary Policy - Recent Changes and New Questions," Finance and Economics Discussion Series 76, Board of Governors of the Federal Reserve System, 2013.

Evans, C. L., "Monetary Policy in a Low-Inflation Environment: Developing a State-Contingent Price-Level Target," Journal of Money, Credit and Banking 44 (02 2012), 147-155.

Fisher, I., Stabilized Money (London: Allen \& Unwin, 1935).

Fregert, K. And L. Jonung, "Deflation Dynamics in Sweden: Perceptions, Expectations, and Adjustment During the Deflations of 1921-1923 and 19311933," in R. Burdekin and P. Siklos, eds., Deflation: Current and Historical Perspectives (Cambridge, New York: Cambridge University Press, 2004), 91128.

Galí, J. And T. Monacelli, "Monetary Policy and Exchange Rate Volatility in a Small Open Economy," Review of Economic Studies 72 (2005), 707-734.

Grytten, O. H., "The Scale of Norwegian Interwar Unemployment in International Perspective," Scandinavian Economic History Review 43 (1995), 226250 .

Hatcher, M. And P. Minford, "Stabilization Policy, Rational Expectations and Price-Level versus Inflation Targeting: A Survey," CEPR Discussion Paper 9820, 2014.

Hedberg, P., "Bilateral Exchange Clearing with Germany during the 1930s: the Experiences of the Scandinavian Countries," in S.-O. Olsson, ed., Managing 
Crises and De-globalisation: Nordic Foreign Trade and Exchange, 1919-1939 (London, New York: Routledge, 2010), 101-120.

Jonung, L., "Cassel, Davidson and Heckscher on Swedish Monetary Policy: A Confidential Report to the Riksbank in 1931," Economy and History 22 (1979a), 85-101.

—_, "Knut Wicksell's Norm of Price Stabilization and Swedish Monetary Policy in the 1930s," Journal of Monetary Economics 5 (1979b), 459-496.

Justiniano, A. And B. Preston, "Can Structural Small Open-Economy Models Account for the Influence of Foreign Disturbances?," Journal of International Economics 81 (May 2010a), 61-74.

_ - "Monetary Policy and Uncertainty in an Empirical Small Open-Economy Model," Journal of Applied Econometrics 25 (2010b), 93-128.

KindleBerger, C. P., The World in Depression. 1929-1939 (London: Allen Lane The Penguin Press, 1973).

Kocherlakota, "Monetary Policy Report to the Minnesota Business Partnership, 8 July 2014," WwW.minneapolisfed.org/news_events/pres/kocherlakota_speech_July8_2014.pdf, 2014 .

Krugman, P. R., "It's Baaack: Japan's Slump and the Return of the Liquidity Trap," Brookings Papers on Economic Activity 29 (1998), 137-206.

Lester, R. A., Monetary Experiments: Early American and Recent Scandinavian (Princeton: Princeton University Press, 1939).

LEVy-Yeyati, E. AND F. SturzenEgGer, "Classifying exchange rate regimes: Deeds vs. words," European Economic Review 49 (August 2005), 1603-1635. 
Lindahl, E., "Der Übergang zur Papierwährung in Schweden 1931," Weltwirtschaftliches Archiv 43 (1936), 82-96.

Lubik, T. A. And F. Schorfheide, "A Bayesian Look at the New Open Economy Macroeconomics," in NBER Macroeconomics Annual 2005, Volume 20 (National Bureau of Economic Research, Inc, 2006), 313-382.

__ , "Do Central Banks Respond to Exchange Rate Movements? A Structural Investigation," Journal of Monetary Economics 54 (May 2007), 1069-1087.

LundBerG, E., Ekonomiska kriser förr och nu (Stockholm: SNS, 1983).

Mitchell, B. R., International Historical Statistics. Europe, 1750-2000 (Houndsmills, Basingstoke: Palgrave Macmillan, 2003).

Monacelli, T., "Monetary Policy in a Low Pass-Through Environment," Journal of Money, Credit and Banking 37 (2005), 1047-1066.

Montgomery, A., How Sweden Overcame the Depression 1930-1933 (Stockholm: Alb. Bonniers Boktryckerei, 1938).

Olsson, S.-O., "Nordic Trade Cooperation in the 1930s," in S.-O. Olsson, ed., Managing Crises and De-globalisation: Nordic Foreign Trade and Exchange, 1919-1939 (London, New York: Routledge, 2010), 17-33.

Rabanal, P. and J. F. Rubio-Ramírez, "Comparing New Keynesian Models of the Business Cycle: A Bayesian Approach," Journal of Monetary Economics 52 (2005), 1151-1166.

Reinhart, C. And K. Rogoff, "The Modern History of Exchange Rate Arrangements: A Reinterpretation," Quarterly Journal of Economics 119 (2004), $1-48$. 
Salmon, P., "British-German Rivalry in Northern Europe Revisited," in S.-O. Olsson, ed., Managing Crises and De-globalisation: Nordic Foreign Trade and Exchange, 1919-1939 (London, New York: Routledge, 2010), 6-16.

SchÖn, L. AND O. Krantz, "Swedish Historical National Accounts 1560-2010," Lund Papers in Economic History 123, 2012.

Smets, F. And R. Wouters, "Openness, Imperfect Exchange Rate PassThrough and Monetary Policy," Journal of Monetary Economics 49 (July 2002), 947-981.

Statistika Centralbyrån, Historisk Statistik för Sverige: Del 3. Utrikeshandel 1732-1970 (Stockholm: Statistika Centralbyrån, 1972).

Straumann, T. And U. Woitek, "A Pioneer in Monetary Policy? Sweden's Price Level Targeting of the 1930s Revisited," European Review of Economic History 13 (2009), 251-282.

Svensson, L. E., "Escaping from a Liquidity Trap and Deflation: The Foolproof Way and Others," Journal of Economic Perspectives 17 (Fall 2003), 145-166.

Thomas, B., Monetary Policy and Crises (London: Routledge, 1936).

Venneslan, C., "Norway's Recovery from the Great Depression - an Act of Balancing?," Scandinavian Economic History Review 58 (2010), 119-138.

Woodford, M., Interest and Prices: Foundations of a Theory of Monetary Policy (Princeton, NJ: Princeton University Press, 2003). 